\title{
A Study Of Quality Management In Small Organizations Providing Services Directed At People
}

Joseph N. Khamalah (E-mail: khamaljn@ipfw.edu) Indiana University Purdue University, Fort Wayne B.P. Lingaraj (E-mail: lingaraj@ipfw.edu) Indiana University Purdue University, Fort Wayne

\begin{abstract}
This paper reports on a study of managerial perceptions of the implementation of total quality management (TQM). Results of a survey covering small firms in northeastern Indiana providing services directed at people are presented. Aspects discussed include the unique nature of this category of service firms, TQM deployment, tools used, successes, failures, benefits, and problems encountered. The majority of respondents indicated their firms' commitment to TQM but a significantly smaller proportion demonstrated notable engagement with and actual implementation of a formal TQM program. Even smaller percentages had benchmarked internal quality standards, used TQM tools and quality-enhancing activities, rewarded employees for successful quality performance, and involved suppliers in their quality programs. Strategic implications of these findings are considered.
\end{abstract}

\section{Introduction}

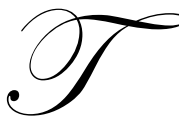

his paper discusses the findings of a survey of perceptions regarding total quality management (TQM) practices in small firms rendering services whose direct recipients are people. TQM has preoccupied the attention of both business and academic communities, first in manufacturing and then more recently in the service sector ever since the tremendous success of Japanese companies driven by quality-oriented approaches jolted the American economy into redesigning its management practices in the last couple of decades [9, $11,12,17]$. The days when "service with a smile" used to be all it took to satisfy a customer are long gone. Today, customers have become increasingly discerning and are demanding high quality in products, services, and in life [16].

Small business firms today employ more people than big firms. For instance McDonalds' franchises are collectively the largest employer in the U.S. Quality in small businesses attracts as much attention as is the case in large organizations. For instance, the International Standards organization (ISO) has publications addressing the implementation of ISO 9001-based quality management systems for small organizations [8]. This is even reflected in the Malcolm Baldridge National Quality Awards - out of the 49 organizations applying for the 2002 awards, only 8 were large manufacturers. The rest were: 3 service, 10 educational, 17 health care, and 11 small business firms [2]. The intersection of 'service' and 'small' is indeed important as evidenced by frequent coverage in both the popular press and practitioner periodicals of instances of poor service $[7,13]$. Despite this, there is a dearth of material in the literature regarding the status of total quality management in small firms.

Complaints about poor quality and customer service seem to be universal. Paton refers to this as "aggressively bad customer service" [13]. Poor quality is very expensive for firms. This cost can be even more onerous for service firms given the proclivity of people to sue and/or recount their good or bad service experiences to friends, family and colleagues [6]. This penalizes the "offending" service firm on multiple fronts - loss of repeat business,

Readers with comments or questions are encouraged to contact the authors via email. 
unfavorable word of mouth, and a costly legal battle on its hands. The stakes are especially high where the service act is directed at people's bodies and minds for instance health care, food services, and beauty salons. Medical malpractice suits, litigation against restaurants, and liability suits for negligence in settings such as beauty salons are commonplace and quite often do lead to bankruptcies. Hence quality and its deployment in services directed at people is even more crucial than in other types of services.

This study focuses on organizations rendering services directly to people regardless of whether or not the nature of the service act is tangible or intangible. A beauty salon performs a tangible action directed at a customer's body whereas the service act performed by a school is an intangible one directed at a student's mind. This category of service firms is unique since the organization is not isolated from the customer - the latter must physically be present throughout the service act, unlike other sectors such as manufacturing [6]. This intensive interaction between the service organization and the customer in person has profound quality implications for the organization. Ensuring quality and consistency in the service offering is a lot harder to achieve than in other sectors. The organization has no option but to rely extensively on the performance (skills, judgment, and training) of its personnel who render the service act. The disposition of employees assumes far greater significance for, as was so aptly put by some sage you can't get happy customers from unhappy employees. As an example, McDonalds has been losing ground to their competitors because customers perceive that "service with a smile" has been replaced by "service with a sneer."

The scope of this problem is quite large given that the service sector has been growing rapidly in the recent past. For instance 18.5 million people were employed in goods-producing industries and 22.99 million in service providing industries in 1945 in the U.S. These figures had grown to 24.71 million and 97.66 million respectively by 1997 and the gap continues to widen with each passing year [5]. Increasing market deregulation and extensive breakdown of governmental barriers by international agreements (NAFTA, EC, MERCOSUL, GATT, etc) have, in addition, created a global highly competitive environment in such cross-border sectors as financial services [10]. These pressures have spilled over to other service sectors on the domestic front $[1,15]$ with the focus shifting from price to both price and quality.

This study seeks to establish the extent to which TQM has been deployed in this sector. Has TQM been embraced by small firms as much as the big firms? The principal aim of the survey was to explore the views and expectations of managers regarding quality deployment with respect to employment of TQM, tools used, successes, failures, benefits, and problems encountered. In the following section, the specific research issues investigated and the research methods used are discussed. The sections thereafter contain an analysis of service TQM deployment and its successes, failures and reasons thereof. The final section summarizes our conclusions and discusses the strategic implications.

\section{Methodology}

We adopted the commonly used definition of a small business as one having 500 or fewer employees. We developed a survey instrument that included a definition of total quality management. The first part of the instrument had demographic items but respondents did not have to identify themselves. This was followed by a definition of TQM as "a business strategy encompassing the entire organization to provide goods/services that completely satisfy the customer" and 29 Likert-scaled statements covering the areas mentioned above with $1=$ strongly agree, $2=$ agree, $3=$ neutral, $4=$ disagree, and $5=$ strongly disagree.

A total of 285 small businesses in the people-oriented service sector in northeastern Indiana were requested to complete the questionnaire. Businesses represented included full-service and fast food restaurants, caterers, hotels and motels, hair and beauty salons, health and fitness centers, nursing homes, health care providers, churches, educational institutions, and entertainment stores. They were selected from the yellow pages. After verifying that the organization met study criteria and was willing to participate, a questionnaire was sent to the manager of the firm along with a stamped, addressed return envelope. There was telephone follow-up. Firms were offered the opportunity to complete the questionnaire through an interview. 


\section{Demographics}

We received 174 usable responses. This higher than usual response rate $(61.1 \%)$ is attributable to persistent follow-up by students of a production/operations management course. 58\% of the respondents were from top management, $36.2 \%$ from middle management, and 5.7\% from the operational level. $29.3 \%$ of the businesses were family-owned and $14.4 \%$ were partnerships while $46.0 \%$ were publicly owned. Three fourths of the firms had been in existence for at least five years. A significant proportion was fairly small in size in terms of both number of employees and sales revenues. $65.0 \%$ had 50 or fewer employees and $62.6 \%$ had annual sales revenues of less than $\$ 10.0$ million. Table 1 presents the percentage of respondents in each classification category.

Table 1: Demographic Characteristics

\begin{tabular}{|c|c|c|c|c|c|c|}
\hline Item & \multicolumn{6}{|c|}{ Category / Percent of Respondents } \\
\hline $\begin{array}{l}\text { Age of firm } \\
\text { in years }\end{array}$ & $\begin{array}{c}\text { Below } 1 \mathrm{yr} \\
9.8\end{array}$ & $\begin{array}{c}1-3 \text { yrs } \\
5.7\end{array}$ & $\begin{array}{c}3-5 \mathrm{yrs} \\
9.8\end{array}$ & $\begin{array}{c}5-10 \text { yrs } \\
21.8\end{array}$ & $\begin{array}{c}\text { Above } 10 \mathrm{yrs} \\
52.9\end{array}$ & \\
\hline $\begin{array}{l}\text { Type of } \\
\text { ownership }\end{array}$ & $\begin{array}{c}\text { Family } \\
\text { business } \\
29.3\end{array}$ & $\begin{array}{c}\text { Partnership } \\
14.4\end{array}$ & $\begin{array}{c}\text { Public } \\
46.0\end{array}$ & $\begin{array}{c}\text { Not indicated } \\
10.3\end{array}$ & & \\
\hline $\begin{array}{l}\text { Number of } \\
\text { employees }\end{array}$ & $\begin{array}{c}10 \text { or less } \\
32.2\end{array}$ & $\begin{array}{c}11-25 \\
19.0\end{array}$ & $\begin{array}{c}26-50 \\
13.8\end{array}$ & $\begin{array}{c}51-100 \\
12.0\end{array}$ & $\begin{array}{c}101-500 \\
23.0\end{array}$ & \\
\hline $\begin{array}{l}\text { Annual sales } \\
(\$ \mathrm{~m})\end{array}$ & $\begin{array}{c}\text { Less than } 1.0 \\
14.9\end{array}$ & $\begin{array}{c}1.0-2.49 \\
16.7\end{array}$ & $\begin{array}{c}2.50-4.99 \\
13.8\end{array}$ & $\begin{array}{c}5.0-9.99 \\
17.2\end{array}$ & $\begin{array}{c}10.0 \text { or above } \\
20.7\end{array}$ & $\begin{array}{c}\text { Not indicated } \\
16.7\end{array}$ \\
\hline $\begin{array}{l}\text { Management } \\
\text { level of } \\
\text { respondent }\end{array}$ & $\begin{array}{c}\text { Upper } \\
58.0\end{array}$ & $\begin{array}{c}\text { Middle } \\
36.2\end{array}$ & $\begin{array}{c}\text { Operational } \\
5.7\end{array}$ & & & \\
\hline
\end{tabular}

\section{Deployment}

With regard to TQM deployment, the issues investigated included respondents' perceptions of top management commitment to TQM, the presence of a formal TQM program in the firm, the existence of internal quality standards, TQM tools and quality improvement programs (QIPs) used, and involvement of suppliers in TQM efforts. More than two thirds $(69.0 \%)$ of the firms reported that their top management was totally committed to TQM. This was very different from other responses in this category. A much smaller fraction $(59.8 \%)$ agreed or strongly agreed that their organizations had a formal TQM program. Only half of the firms had internal quality standards benchmarked on operations of world-class companies and an even lower proportion employed charts, graphs, statistical quality control, and other QIPs (48.9\%), and used team building techniques like quality circles (44.3\%). A mere $36.2 \%$ of the businesses had their suppliers involved in their TQM program. Table 2 shows these results.

Table 2: TQM Deployment

\begin{tabular}{|l|ccc|}
\hline Statement & \multicolumn{2}{|c|}{ Percent of Respondents } \\
\hline & $\begin{array}{c}\text { Agree/ } \\
\text { Strongly Agree }\end{array}$ & $\begin{array}{c}\text { Disagree/ } \\
\text { Strongly Disagree }\end{array}$ \\
\hline Top management committed to TQM & 69.0 & 21.8 & 9.2 \\
Firm has formal TQM program & 59.8 & 21.3 & 19.0 \\
Firm has benchmarked internal quality standards & 50.0 & 29.3 & 21.7 \\
Firm uses TQM tools and QIPs & 48.9 & 26.4 & 24.7 \\
Firm uses team building techniques such as QCs & 44.3 & 32.2 & 23.5 \\
Suppliers involved in firm's TQM program & 36.2 & 48.9 & 14.9 \\
\hline
\end{tabular}


The 10 percent difference in Table 2 between firms' commitment to TQM and having a formal TQM program suggests the possibility that respondents may have indicated that their top management was totally committed to TQM simply because they thought it would make them look good. The even lower agree/strongly agree responses to the next four items in Table 2 dealing with implementation provide little evidence of actual deployment of TQM in a majority of the firms surveyed. The same is true in other sectors. At a time when quality has supposedly come of age, even manufacturing companies have been found to be using TQM tools and techniques to a rather limited extent $[4,12]$. Also, despite the inclusion of a formal definition in the survey instrument, the respondents may not have been very clear about the meaning of TQM. Some of them may have equated "intention to pursue" TQM with its "actual implementation."

Chi-square tests for independence were used to establish whether any relationships existed between the various statements (variables) investigated. Table 3 lists the variables where the null hypothesis of independence with other variables was rejected at the 0.05 level of significance. This analysis showed that respondents in the upper and middle management levels were more likely to agree or strongly agree that their firms had a formal TQM program than those in the lower management levels. No relationship was noticed between the management level and responses as to whether the firm's top management was committed to TQM, benchmarked its internal quality standards, used TQM tools and QIPs, and team building techniques such as quality circles, or involved suppliers in its TQM program. It was also noticed that respondents whose top management was committed to TQM were more likely to use TQM tools, QIPs, and team-building techniques, and have benchmarked internal quality standards. Similarly, respondents from firms that were family run were more likely to indicate that they involved suppliers in their TQM program and had benchmarked internal quality standards than respondent firms that were partnerships or publicly owned.

Table 3: Variable Dependence/Relationship

\begin{tabular}{|c|c|c|c|c|c|c|}
\hline $\begin{array}{r}\text { Variable } \\
\text { Dependence with }\end{array}$ & $\begin{array}{l}\text { Top mgt } \\
\text { commit- } \\
\text { ment }\end{array}$ & $\begin{array}{c}\text { Formal } \\
\text { TQM } \\
\text { program }\end{array}$ & $\begin{array}{c}\text { Supplier } \\
\text { involved in } \\
\text { TQM }\end{array}$ & $\begin{array}{l}\text { Number of } \\
\text { employees }\end{array}$ & $\begin{array}{l}\text { Employee } \\
\text { training }\end{array}$ & $\begin{array}{l}\text { Employee } \\
\text { rewarded }\end{array}$ \\
\hline Management level & & $\mathrm{X}$ & & & & \\
\hline Type of ownership & & & $\mathrm{X}$ & & & \\
\hline Revenue & & & $\mathrm{X}$ & $\mathrm{X}$ & & $\mathrm{X}$ \\
\hline Top mgt commitment & & $\mathrm{X}$ & & & & \\
\hline Supplier involved in TQM & $\mathrm{X}$ & $\mathrm{X}$ & & & $\mathrm{X}$ & $\mathrm{X}$ \\
\hline Tools, QIPs used & $\mathrm{X}$ & $\mathrm{X}$ & $\mathrm{X}$ & & & \\
\hline Employee training & & $\mathrm{X}$ & $\mathrm{X}$ & & & \\
\hline Team building techniques & $\mathrm{X}$ & $\mathrm{X}$ & $\mathrm{X}$ & & & \\
\hline Employee rewarded & $\mathrm{X}$ & $\mathrm{X}$ & $\mathrm{X}$ & & & \\
\hline Internal quality standards & & & $\mathrm{X}$ & $\mathrm{X}$ & & \\
\hline Lack of top management support & & & $\mathrm{X}$ & & & \\
\hline
\end{tabular}

\section{Personnel and Work Processes}

The study also sought to establish respondents' perceptions regarding their firms' practices in employee training, commitment, responsibility, culture, continuous improvement, and reward systems in connection with quality. In general, the majority of respondents indicated that their organizations were continually making improvements in their work processes, employees are committed to achieving excellence and are responsible for their own work, their organizational culture builds mutual trust, and had employees at all levels undergo extensive training on quality issues. Table 4 summarizes these findings. 
Table 4: Personnel and Work Processes

\begin{tabular}{|l|ccc|}
\hline Statement & \multicolumn{2}{|c|}{ Percent of Respondents } \\
\hline & $\begin{array}{c}\text { Agree/ } \\
\text { Strongly Agree }\end{array}$ & $\begin{array}{c}\text { Disagree/ } \\
\text { Neutral }\end{array}$ & \begin{tabular}{c} 
Strongly Disagree \\
\hline Firm is always making improvements in work processes
\end{tabular} \\
Employees committed to achieving excellence in TQM & 93.7 & 2.9 & 3.4 \\
Employees responsible for their own work & 80.2 & 7.5 & 2.3 \\
Firm's organizational culture builds mutual trust & 78.1 & 5.7 & 6.4 \\
Firm's employees undergo extensive quality training & 75.9 & 16.7 & 5.2 \\
Employees who successfully apply TQM are rewarded/recognized & 54.0 & 14.9 & 9.2 \\
\hline
\end{tabular}

Responses to the first five statements in this section were not at all surprising. The overwhelming majority (more than three quarters of all respondents) agreed or strongly agreed with the statements as posed in the survey instrument. In marked contrast to these, however, a little over half of the respondents (54.0\%) agreed with the statement that employees who successfully applied TQM were rewarded or recognized. This does not match the agree/strongly agree responses on top management commitment to TQM, continuous improvements in work processes, employee quality training, culture of mutual trust, employee commitment to TQM, and employees being responsible for their own work. It suggests that the bulk of agree/strongly agree responses to the first five survey statements in this category may simply have been "lip service" or the 'politically correct' thing to say about the firm, or that the majority of firms in this sector are yet to follow through on their implementation of TQM.

The foregoing also signifies that most firms' commitment to TQM was higher than their commitment to rewarding employees for quality performance. In quality-conscious organizations, high quality is everybody's business [16] and it has to be buttressed by a reward system that recognizes successful instances of quality accomplishments. The malaise that these results point to, however, is not the exclusive domain of people-oriented service firms. Other studies have shown that even in the manufacturing sector, most firms' TQM programs are yet to evolve to that stage and time where the importance of tying reward systems to quality performance is recognized [12].

\section{Customer Issues}

The third category of issues surveyed covered the extent to which customer satisfaction is incorporated into the firm's quality program. This category goes to the root of the definition of TQM included in the survey instrument. A summary of the responses is presented in Table 5. More than three quarters of the respondents stated that their organization involved customers heavily in the design and delivery of service, used various mechanisms of assessing customer satisfaction and had in place a system for handling customer complaints. The non-zero proportion disagreeing or being neural to this category of survey statements suggests, as does the literature, that there is always room for improvement in this area.

Table 5: Customer Issues

\begin{tabular}{|l|ccc|}
\hline Statement & \multicolumn{3}{|c|}{ Percent of Respondents } \\
\hline & $\begin{array}{c}\text { Agree/ } \\
\text { Disagree/ } \\
\text { Strongly Agree }\end{array}$ & $\begin{array}{c}\text { Neutral } \\
\text { Strongly Disagree }\end{array}$ \\
\hline Firm handles complains effectively to earn customer loyalty & 93.1 & 5.2 & 1.7 \\
Firm systematically assesses customer satisfaction & 88.5 & 8.1 & 3.4 \\
Firm has a thorough system of identifying customer wants & 77.6 & 13.8 & 8.6 \\
Firm incorporates features to delight the customer & 70.7 & 218 & 7.5 \\
\hline
\end{tabular}


Customer satisfaction is the key to the success of firms in this part of the service sector. That about $30 \%$ of the responding firms do not agree with the statement that their firms try to delight the customer and $22.4 \%$ do not agree that their firms systematically identify customer wants is a telling tale. A lot more firms involved in service acts directed at people should pay serious attention to customer satisfaction.

\section{Conclusions}

It has been averred that everybody wants high quality and the worker or executive who proclaims a need for low quality is yet to be found [16]. Despite this, there is a lot of anecdotal evidence pointing to the fact that service quality in the U.S. is not where most people would like it to be. The situation is even more onerous in sectors where services provided by firms are directed at customers' bodies or minds. The problem is not one that should concern only consumers of the services, for, as was pointed out earlier, the effect of poor quality may be more damaging to the service providing firm in terms of loss of repeat business, bad word of mouth, and legal suits that could have been avoided in the first place. Perhaps, as has been suggested, the old saying of caveat emptor (let the buyer beware) should be changed to caveat venditor (let the seller beware) [13]. Little empirical evidence exists about this state of affairs in small firms especially in sectors wherein people are the direct recipients of services rendered. The main objective of this survey was to help shed some light on this.

In sum, the survey results highlight inconsistencies in how small organizations in this sector perceive and implement total quality management programs. Although the vast majority of small firms surveyed state that they are committed to TQM, the survey results suggest that these programs may not have been properly implemented. This is in line with conclusions others have reached that quality levels even in six sigma programs in many companies have sunk to points below initial levels in a couple of years after deployment due to lack of commitment and implementation [18]. Part of the problem may stem from different levels of management perceiving it in different lights. There is obvious need for the entire organization to be in agreement with regard to TQM deployment, supplier involvement, use of TQM tools, QIPs, employee quality training, and establishment and use of benchmarked standards.

The area of employee reward or recognition for quality performance and training of employees in quality stand out in the survey results - with an obvious need for the majority of firms to raise their commitment in these areas to the same levels as their reported commitment to TQM. This is particularly critical for firms providing services directed at people's bodies and minds. More fundamentally, these survey results do suggest that US practices still stand out in marked contrast with those in Japanese firms wherein TQM is perceived differently - as being important in both service and manufacturing and buttressed by the appropriate TQM tools, QIPs, reward systems and supplier involvement [3]. Juran, one of the acknowledged quality gurus, maintains that with relatively few exceptions, the United States currently is still below the Japanese as far as quality of products and services is concerned despite decades of improvements [14]. Studies, such as the current one, may be sounding the clarion call for American business to place less emphasis on short-term financial payoffs, nurture the workforce as a resource, build in quality, and get back to basics.

\section{References}

1. Al-Assaf, A.F., and S.J. Gentling. "Executives' Perception of Total Quality Improvement”, Hospital Topics 74, no. 1 (1996): 26-30.

2. "Baldridge Process News", http://www.quality.nist.gov accessed September 2, 2002.Chaudhry, P.E., and S.S. Chaudhry. "Managerial Perceptions of Quality Control in Japanese Businesses", Production and Inventory Management Journal 41, no. 4 (2000): 34-39.

4. Dowlatshahi, S. "The Role of Purchasing and TQM in the Maquiladora Industry", Production and Inventory Management Journal 39, no. 4 (1998): 42-49.

5. Evans, J.R., and W.M. Lindsay. The Management and Control of Quality. Cincinnati, OH: South-Western, 2001.

6. Fitzsimmons J. A. and M. J. Fitzsimmons. Service Management: Operations, Strategy, and Information Technology. New York, NY: McGraw-Hill, 2000. 
7. $\quad$ Godfrey A. B. “Service Quality: Still an Oxymoron?”, Quality Digest 22, no.7 (2002): 16.

8. International Standards Organization. "ISO 9001 for Small Businesses: What to do", http://www.iso.org accessed September 2, 2002.

9. Kannan, V.R., K. Tan, R.B. Handfield, and S. Ghosh. "Quality in the Boardroom and on the Shop Floor: A Survey of Contemporary Quality Practice", Production and Inventory Management Journal 41, no. 4 (2000): 1-7.

10. Longco, C.R., and M.A. Cox. "Total Quality Management in Financial Services: Beyond the Fashion the Reality Takes Off”, Total Quality Management 8, no. 6 (1997): 323-333.

11. Malhotra, M.D., D.C. Steele, and V. Grover. "Important Strategic and Tactical Manufacturing Issues in the 1990s", Decision Sciences 25, no. 1 (1994): 189-214.

12. McCarthy, P.M., and T.J. Keefe. "A Measure of Staff Perceptions of Quality-oriented Organizational Performance: Initial Development and Internal Consistency", Journal of Quality Management 4, no. 2 (1999): 185-206.

13. Paton S. M. “Grading Customer Service: The Customer Isn't Always Right Anymore”, Quality Digest 22, no.7 (2002): 6. (See also "Caveat Venditor: Let the Seller Beware", Quality Digest 22, no.8 (2002): 4.)

14. Paton S. M. "Juran: A Lifetime of Quality. An Exclusive Interview with a Quality Guru", Quality Digest 22, no. 8 (2002): 19-23.

15. Singh, S., and S.G. Deshmukh. "Quality Initiatives in the Service Sector", Total Quality Management 10, no. 1 (1999): 5-16.

16. Sureshchandar, G.S., C. Rajendran, and R.N. Anantharaman. "A Conceptual Model for Total Quality Management in Service Organizations", Total Quality Management 12, no. 3 (2001): 343-363.

17. Zain, Z.M., B.G. Dale, and F. Kehoe. "Doctoral TQM Research: A Study of Theses, Directions and Trends", Total Quality Management 12, no. 5 (2001): 599-609.

18. Zwirn, H.A. "Bringing Change and Project Management Together - Some Real-Life Examples", Keynote Speech at the $9^{\text {th }}$ Annual APICS Educational \& Research Foundation Academic/Practitioner Summer Workshop, Wilmerding, PA, July 19, 2002.

Notes 
Notes 